\title{
SALINITY AND PHYSICOCHEMICAL WATER PARAMETERS OF THE LOWER FLOW OF NERETVA RIVER
}

\author{
Anita Ivanković \\ University of Mostar, Faculty of Agronomy and Food Technology, Associate professor \\ Corresponding author: anitaivankovic@gmail.com \\ Predrag Ivanković \\ University of Mostar, Faculty of Agronomy and Food Technology, Assistant professor \\ Danijela Petrović \\ University of Mostar, Faculty of Agronomy and Food Technology, Assistant professor \\ Tea Anđelić \\ University of Mostar, Faculty of Agronomy and Food Technology, Student \\ Jerina Majstorović \\ University of Mostar, Faculty of Agronomy and Food Technology, Sc. Ing. Agr.
}

Professional paper / Stručni rad

(Received: 22 May 2017; accepted: 2 November 2017)

\begin{abstract}
The lower flow of the Neretva River (delta) covers approximately 20.000 hectares. This is a unique, humid Mediterranean area with a number of important and protected wetland habitats and is a ornithological, ichthyology, and botanical reserve. By measuring the physico-chemical parameters at 20 locations, the water quality was determined with special attention to the occurrence of salinity. Increasing salinity of the Neretva water was found, owing to inflow reduction groundwater of the river Trebišnjica and the uncontrolled deepening of the Neretva riverbed. During a one-year monitoring period, field tests were conducted of significant maritime impacts on water quality. The physical parameters were the measured temperature, conductivity, electrical resistance, salinity, chemical quantity of dissolved oxygen (expressed as a percentage, $\mathrm{mg} \mathrm{L}-1$ ), the oxygen pressure in water, and the $\mathrm{pH}$ value. The values of the above parameters were measured in the field with WTW multiparameter instruments.
\end{abstract}

Keywords: the Neretva River; lower flow; salinity; water quality

\section{SALINITET I FIZIČKO-KEMIJSKI POKAZATELJI KVALITETE VODE DONJEG TOKA RIJEKE NERETVE}

Sažetak: Donji tok rijeke Neretve (delta) obuhvaća oko 20.000 hektara. To je jedinstveno vlažno mediteransko područje s brojnim važnim i zaštićenim močvarnim, ornitološkim, ihtiološkim i botaničkim rezervatima. Mjerenjem fizičko-kemijskih pokazatelja kvalitete vode na 20 lokacija, posebna pozornost dana je pojavi povišenog saliniteta. Porast saliniteta u neretvanskom bazenu uzrokovan je smanjenim dotokom podzemnih voda rijeke Trebišnjice i nekontroliranim produbljivanjem korita rijeke Neretve. Tijekom jednogodišnjeg monitoringa izvedena su terenska mjerenja važnog maritimnog utjecaja na kvalitetu vode. Mjereni su fizički pokazatelji - temperatura, električna vodljivost, električna otpornost i salinitet, a od kemijskih - količina otopljenog kisika izražena kao \%, mg L-1 i tlak otopljenog kisika u vodi te pH vrijednost. Mjerenja su izvedena na terenu s kombiniranim WTW višeparametarskim instrumentima.

Ključne riječi: Neretva; donji tok; salinitet; kvaliteta vode

Ivanković, A, Ivanković, P, Petrović, D, Anđelić, T, Majstorović, J 


\section{INTRODUCTION}

The Neretva River is the largest river of the Adriatic catchment area. It flows $203 \mathrm{~km}$ through Bosnia and Herzegovina, and the last $22 \mathrm{~km}$ through Croatia. The water regime in the lower course of the Neretva River is very complex because of the downstream side impact and the hydropower system on the upstream side. The sea inflow into the aquifer and the surface flows of the valley depends on the amount of flow of fresh water from the basin. In the dry season, when inflows from the catchment are reduced and of longer duration, the flow cannot be drawn into the bed of the river in the form of a salt "wedge," and in the aquifer rises from deeper layers to the surface. This phenomenon extends deep upstream in the river valley. The Neretva plains expand into the largest alluvial delta of the Adriatic area. The area is 24,585 ha, of which 12,000 ha are in Croatia and the rest in Bosnia and Herzegovina. In the Upper Herzegovina part of the delta, with an area of 7,411 hectares, the wetland is an area called Hutovo Blato [1].

Apart from the natural effect of the quality of water systems, the situation is exacerbated by human activity. Mainly, the quality of the surface water is under constant influence of sediment substrate, and is largely influenced by climatic factors (temperature and rainfall) [2].

The water regime in the lower course of the Neretva River is very complex because of the impact of the downstream side and the hydroelectric system on the upstream side, in particular the HE Mostar and HE Svitava power plants. All of this influences the quality of water of the Lower Neretva. On the one hand, there is multiyear reduction of the groundwater inflow of fresh water from the river Trebišnjica, and uncontrolled deepening of the riverbed of the Neretva River. On the other hand, there is a sea-level rise owing to global warming, leading to an increase in the salinity of the water in the Neretva basin [3].

Salty water constantly penetrates into underground waterways, leading to the salinity of the soil and a reduction in arable land intended for intensive planting of vegetable crops, as well as the continuous pumping of large quantities of water from underground [4].

In the dry season, when the inflow of the basin is reduced and of longer duration, it is not retractable into the river in the form of a salt "wedge." In addition, the aquifer is raised from the deep layers of the ground surface. This phenomenon extends deep upstream in the river valley. Intrusion into the aquifer and into surface water valleys depends on the amount of fresh water inflow from the catchment [5].

The aim of this study was to measure the physical parameters (temperature, conductivity or CND, and total dissolved salts or TDS) and chemical parameters (dissolved oxygen content, expressed as a percentage; mg L-1 in water; and pH) at 20 locations of significant tests of the maritime influence on the quality of water. The values of these parameters are measured in the field using combined meter WTW Multiparameter Instruments. Special attention is given to the measurement of salinity.

Salinity is expressed as a fraction of dissolved salt per thousand parts of water (ppt or parts per thousand = $\mathrm{g} / \mathrm{kg}=\%$ ). High salinity contributes sodium and chloride ions, the ingredients in sodium chloride, known as common salt. Bays and river mouths have a very wide range of salinity because in these places there is a mixing of fresh and salt water. The salt content in the water an important factor in indicating which groups of organisms can be found in the water [6].

This study also provides a proposal for the future research and protection of that area.

\section{MATERIALS AND METHODS}

\subsection{Sampling locations}

For the purpose of sampling and research, 20 locations were selected (Figure 1) for testing the maritime impact on water quality [7]. Selected locations ranged from Žitomislić in the north to Gabela in the south, including Trebižat in the west and Deransko Lake in the east. The altitude range is from $0 \mathrm{~m}$ (Deransko Lake and Krupa) to $32.5 \mathrm{~m}$ (Bivolje Polje). 


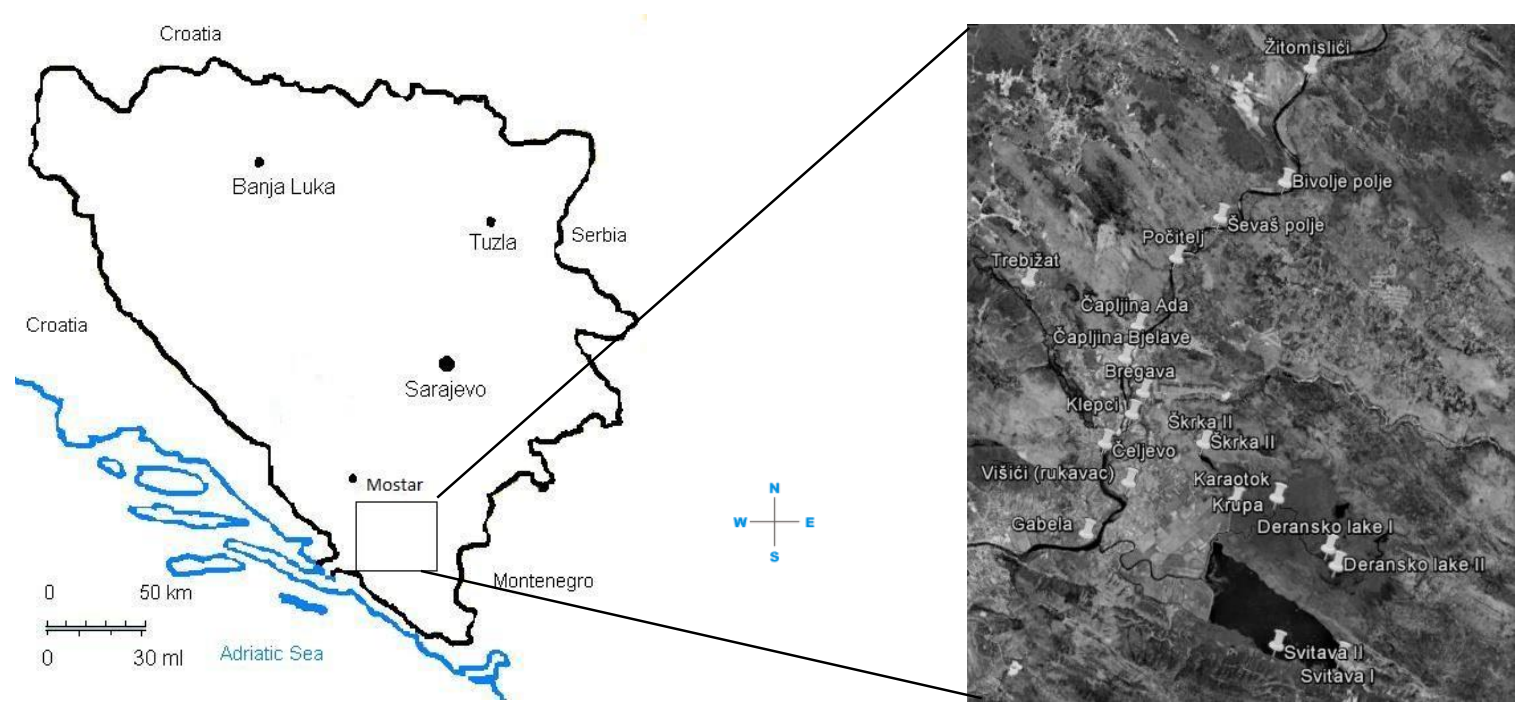

Figure 1 Map of lower flow of the Neretva River with marked measuring locations

\subsection{Water analysis}

The values of all parameters were measured on the ground with WTW multiparameter instruments. Measurements were carried out on six dates during a year in the field at all locations. Six outings in the field covered four seasons and the highest and lowest water levels.

Physicochemical analyses were carried out using standard methods [8]. The accuracy of each method is prescribed by the APHA methodology. The device has three separate electrodes intended for measuring these parameters. Each of them can measure the temperature of water.

The measuring range for electrical conductivity (CND) is from $1 \mu \mathrm{Scm}^{-1}$ to $2 \mu \mathrm{Scm}^{-1}$ (in a temperature range of $-5^{\circ} \mathrm{C}$ to $80^{\circ} \mathrm{C}$ ). The unit for measuring salinity is a practical salinity unit (PSU). The measuring range for total dissolved solids (TDS) was $0 \mathrm{mg} \mathrm{L}^{-1}$ to $1999 \mathrm{mg} \mathrm{L}^{-1}$ in a temperature range of $-5^{\circ} \mathrm{C}$ to $80^{\circ} \mathrm{C}$. Dissolved oxygen was measured by an oxygen electrode. The values are in $\mathrm{mg} \mathrm{L}^{-1}$. Oxygen saturation was measured in the same manner, and the displayed value was expressed as a percentage $\left(\% \mathrm{O}_{2}\right)$. pH was measured by a pH electrode device WTW multiparameter instrument.

\subsection{Statistical analysis}

The data were processed using methods of descriptive statistics. The studied parameters are described numeric values: range or difference between the maximum and minimum values, medium or average values, standard deviation or deviations from the mean values, and the coefficient of variation.

In order to establish the existence of certain causal relationships between the studied parameters, comparisons were made using a correlation to establish a connection. This was numerically expressed by Pearson correlation coefficient.

Statistical analysis was performed using Microsoft Excel.

\section{RESULTS AND DISCUSSION}

\subsection{Water quality analysis}

Climate factors that affect the temperatures measured during monitoring in the lower course of the Neretva River showed no uniform trends but did show significant fluctuations in the measured values. The minimum temperature at all locations was measured in January. This temperature was expected to be highest in July 2016, which confirms the great influence that air temperature has on water temperature. Water temperatures were in the range of \pm 24.5 ${ }^{\circ} \mathrm{C}$, and low temperatures ranged from $4.3^{\circ} \mathrm{C}$ to a maximum of $28.8^{\circ} \mathrm{C}$ (Figure 2).

Ivanković, A, Ivanković, P, Petrović, D, Anđelić, T, Majstorović, J 
January water temperatures were in the range of $\pm 8.20^{\circ} \mathrm{C}$. The lowest temperature $\left(4.3^{\circ} \mathrm{C}\right)$ was measured at Krupa, and the highest $\left(12.5^{\circ} \mathrm{C}\right)$ at Škrka II. The lowest July temperature was measured at Bjelave Čapljina (17 ${ }^{\circ} \mathrm{C}$ ), and the highest July temperature of $28.8^{\circ} \mathrm{C}$ was measured at Svitava I. The temperature measurement during the July was in the range of $\pm 11.8^{\circ} \mathrm{C}$. At least six measurements of water temperature changes were recorded at Ada Čapljina $\left( \pm 6.8^{\circ} \mathrm{C}\right)$. A maximum temperature was measured at Svitava I, where the water temperature was in the range of $\pm 19.9^{\circ} \mathrm{C}$.

In summary, the water temperatures in the river flow are not constant and change under the influence of air temperature (climate), the temperature of water which is supplied, and the depth, length, and speed of the water flow.

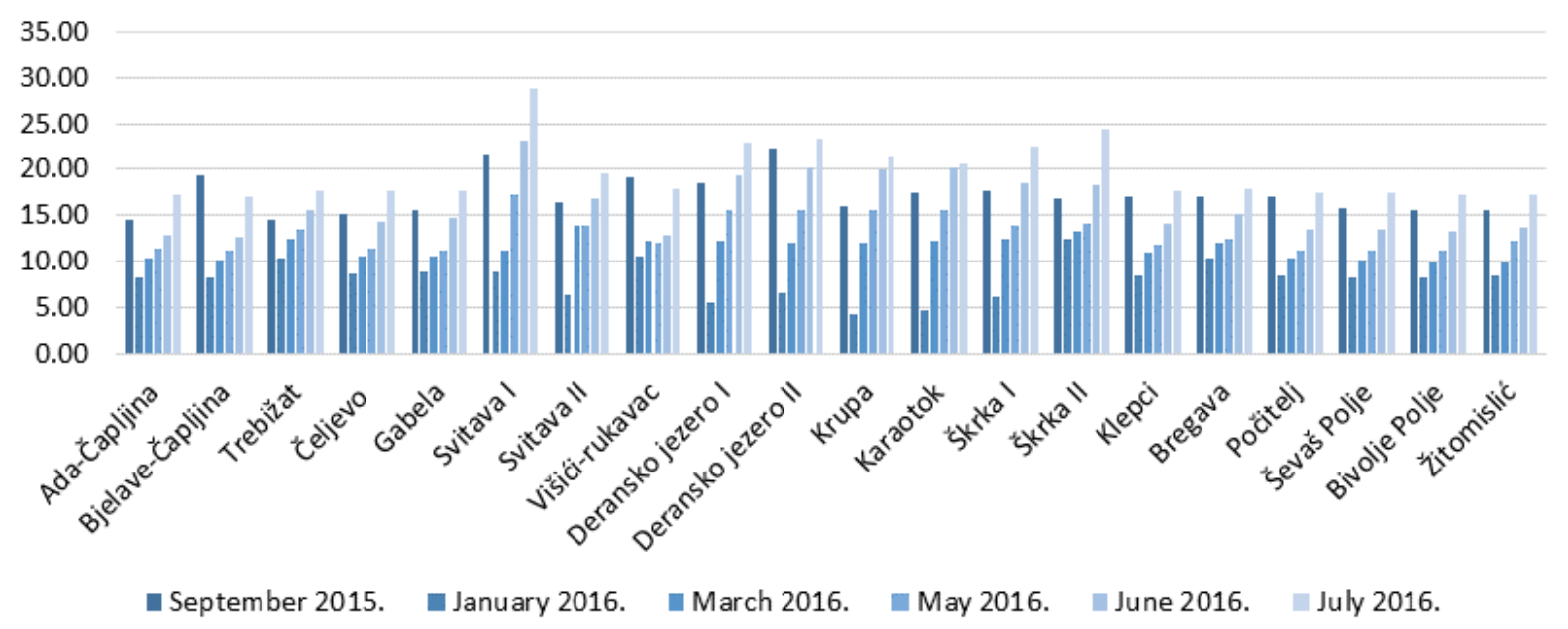

Figure 2 Temperature variations $\left({ }^{\circ} \mathrm{C}\right)$ during research period

The measured value of electrical conductivity can assess the degree of mineralization of water, and also evaluate the type of water (Walton, 1989). Accordingly, the water at Karaotok, Škrka I, and II Škrka, with an electrical conductivity value of more than $1000 \mu \mathrm{S} \mathrm{cm}^{-1}$, are classified as brackish water [9].

The maximum value of electrical conductivity (CND) was measured in March 2016 at Škrka II $\left(2680 \mu \mathrm{Scm}{ }^{-1}\right)$, and the lowest at Bivolje Polje in July of the same year $\left(39 \mu \mathrm{S} \mathrm{cm}^{-1}\right)$. Škrka II had the largest oscillation value of CND, which was in the range of $204 \mu \mathrm{S} \mathrm{cm}^{-1}$ (measured in January 2016) to $2680 \mu \mathrm{S} \mathrm{cm}-1$ in March $( \pm 1721.5 \mu \mathrm{S}$ $\mathrm{cm}^{-1}$ ) (Figure 3).

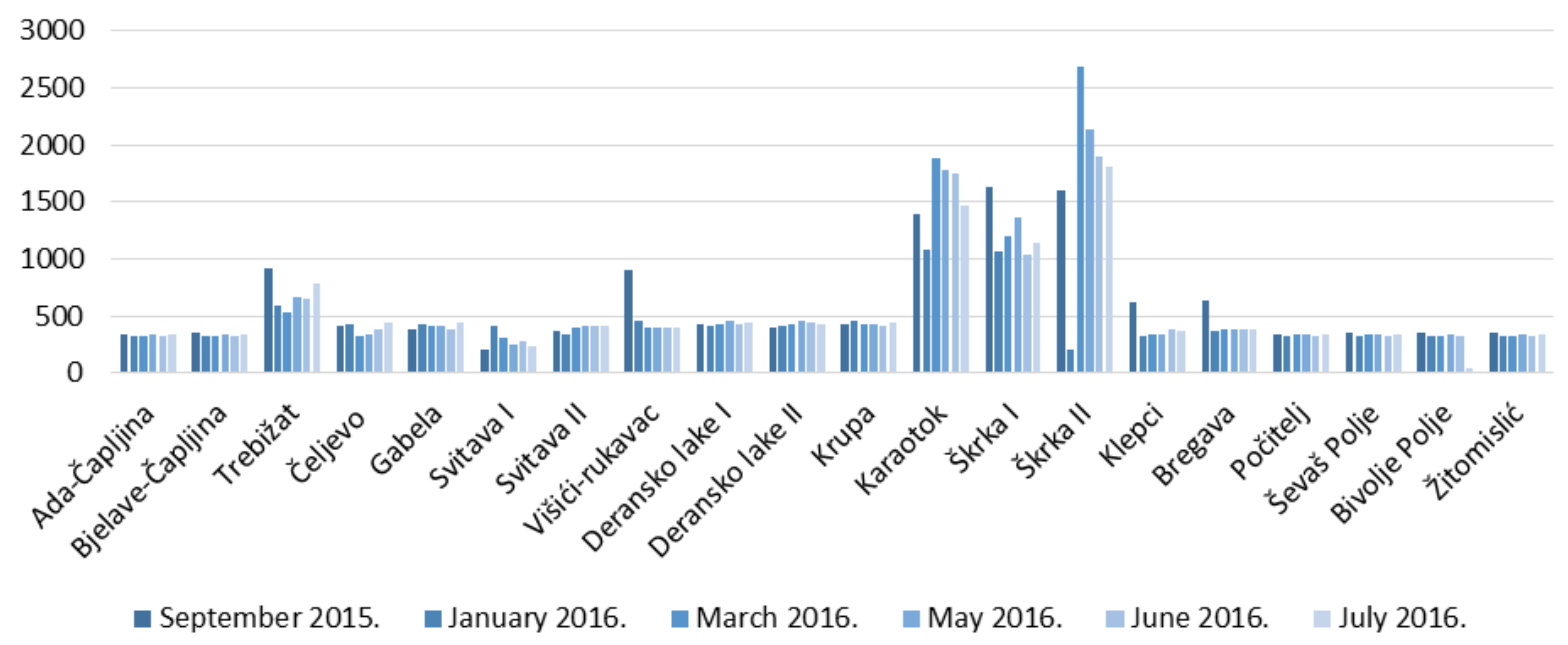

Figure 3 Conductivity $\left(\mu \mathrm{S} \mathrm{cm}^{-1}\right)$ variations during research period

Ivanković, A, Ivanković, P, Petrović, D, Anđelić, T, Majstorović, J 
The maximum value of the electrical resistance $(\rho)$ (Figure 4) was measured in September 2015 at Svitava I $(4.8 \mathrm{k} \Omega \mathrm{cm})$, and the lowest at Škrka II in March $2016(0.347 \mathrm{k} \Omega \mathrm{cm})$.

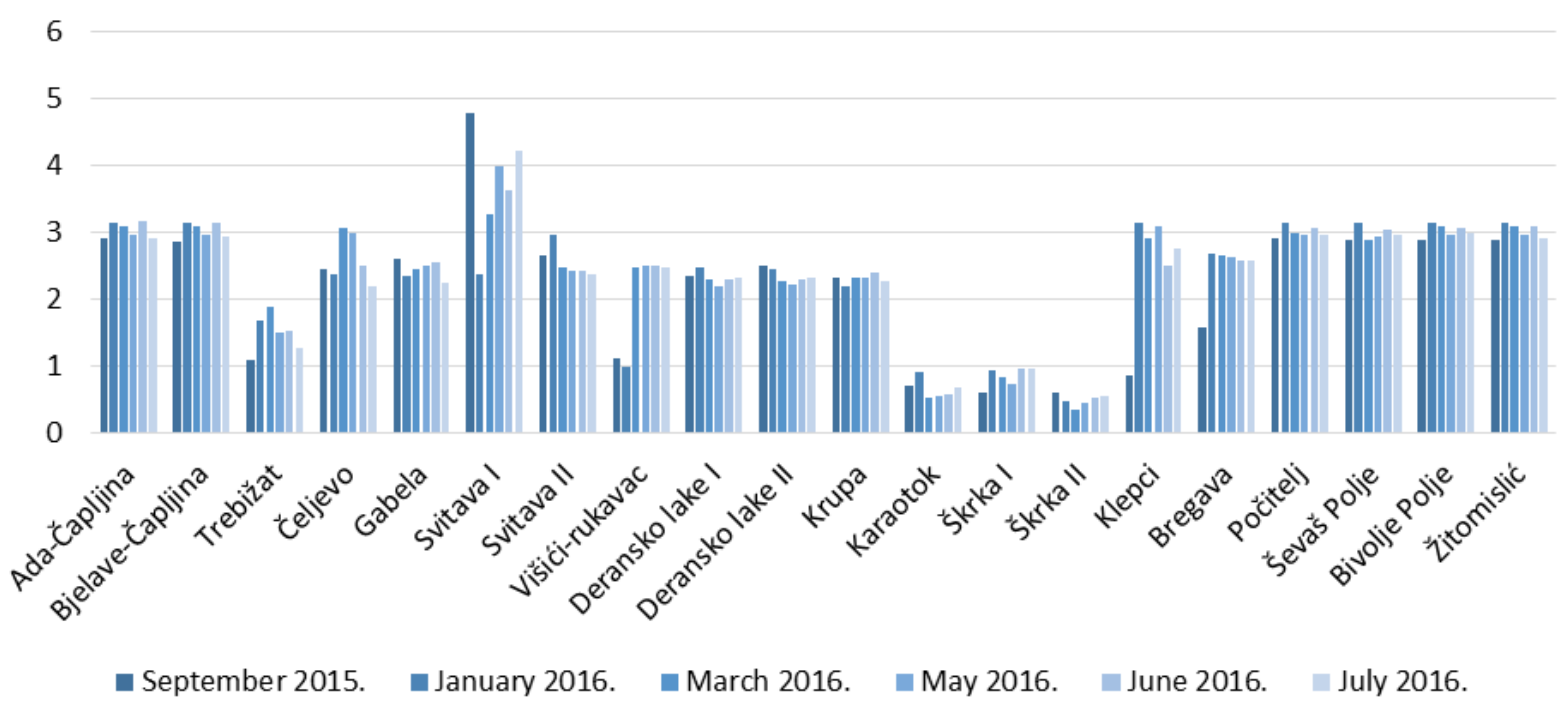

Figure 4 Electrical resistance $(\mathrm{k} \Omega \mathrm{cm})$ variations during research period

The waters of the lower course of the Neretva River are exposed to salinization, and the main cause of salinization is proximity to the sea. The mouth of the Neretva riverbed is very deep ( 9 to $11 \mathrm{~m}$ ) and can be treated as a small bay. This is suitable for the penetration of seawater upstream, especially at low water levels when the Neretva flows with lower energy. In the summer months, especially during high tide, the size and penetration of the salt wedge are strengthened. It is denser and heavier, is under a layer of fresh river water, and flows upstream [10].

This research shows that the greatest salinity of water in the lower flow of the Neretva River was measured at Škrka II in March 2016 (1.5 PSU). The lower salinity of the river is in the range $\pm 1.5 \mathrm{PSU}$, and the average is $0.23 \mathrm{PSU}$ (Figure 5). The lowest average salinity in the water was at Svitava I (AS $=0.033$ PSU). It is seen that salinity increases with increasing temperature in summer and spring, when the reduced upstream water flows.

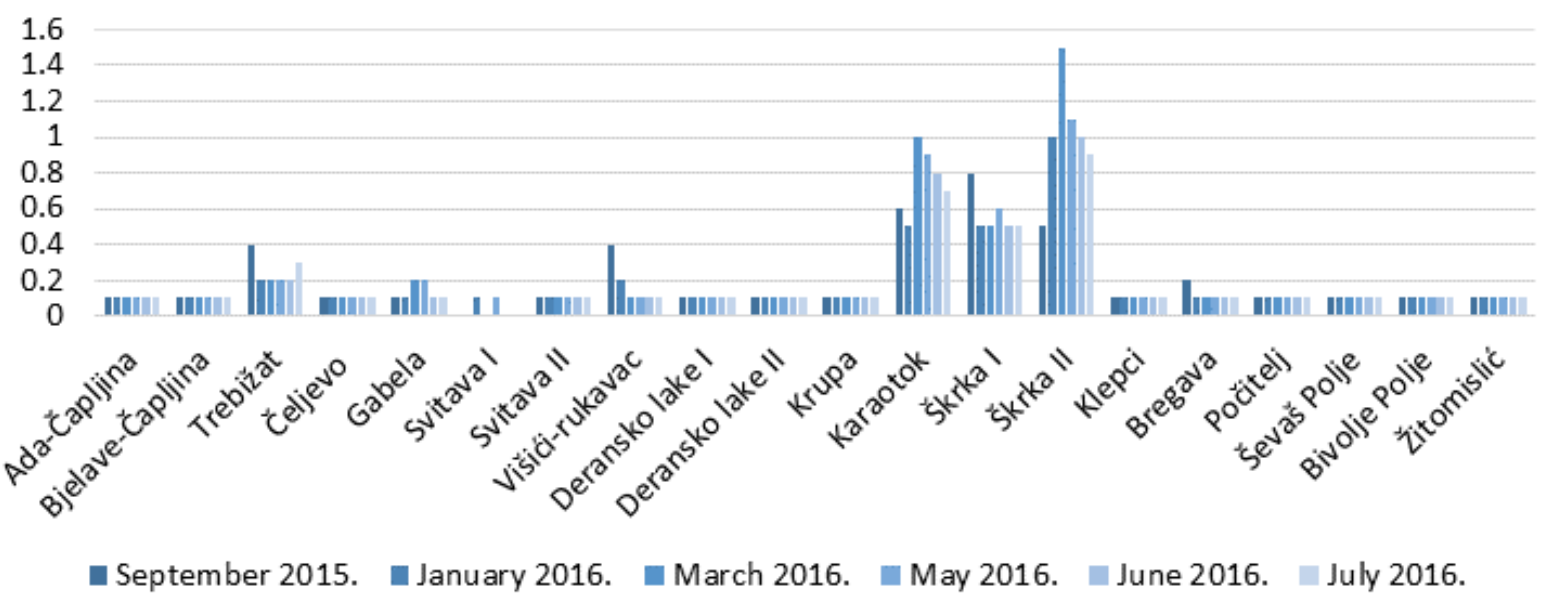

\section{Figure 5 Salinity (PSU) variations during research period}

It is important to point out in the context of increased salinity that the altitudes of locations with increased salinity are not the lowest in the researched area. This implies that groundwater flows may also affect the increase in salinity. This statement is offered as a possible option, but additional studies should be carried out for its confirmation. 
As expected, the same locations also have increased electrical conductivity and total dissolved solids but less dissolved oxygen. Only Trebižat does not show a decreased amount of dissolved oxygen, which can be caused by the faster stream flow of the river.

The total dissolved solids in water of the lower Neretva range from a minimum of $203 \mathrm{mg} \mathrm{L}^{-1}$ (measured in January 2016 at Škrka II) to $2680 \mathrm{mg} \mathrm{L}^{-1}$ (in the same location in March 2016), and the measured values are in the range of $\pm 2477 \mathrm{mg} \mathrm{L}^{-1}$ (Figure 6).

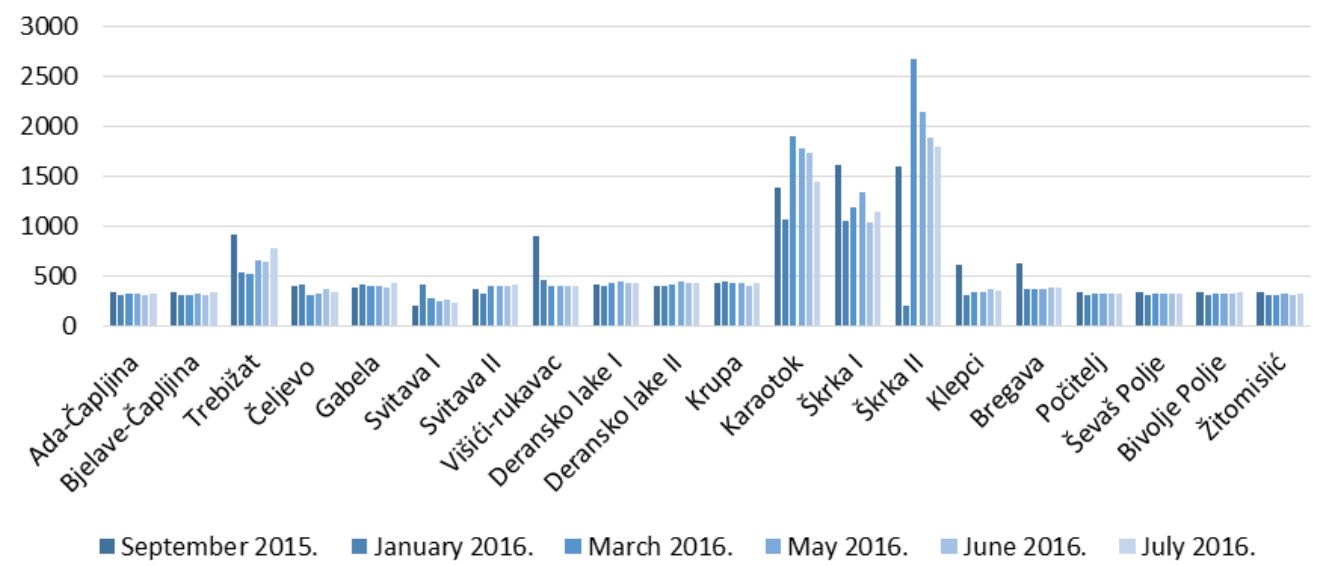

Figure 6 Total dissolved solids ( $\mathrm{mg} \mathrm{L}^{-1}$ ) variations during research period

All values of dissolved oxygen at all locations were in the range of $\pm 8.6 \mathrm{mg} \mathrm{L}^{-1}$ (Figure 7 ), and the average value of dissolved oxygen at all locations was $10.23 \mathrm{mg} \mathrm{L}^{-1}$. The highest amount of dissolved oxygen was measured in January 2016 at Klepci $\left(12.6 \mathrm{mg} \mathrm{L}^{-1}\right)$, and the lowest in July at Karaotok $\left(4 \mathrm{mg} \mathrm{L}^{-1}\right)$. According to the regulation on classification of waters B\&H [11], these are of high quality water (I class). The water at Karaotok is the exception, where the determined average of dissolved oxygen was $6.64 \mathrm{mg} \mathrm{L}^{-1} \mathrm{O}_{2}$, classifying it as second-quality class according to the regulation on classification of waters $\mathrm{B} \& \mathrm{H}$. The moderate best representations of dissolved oxygen in water were located at Žitomislić (11.82 $\left.\mathrm{mg} \mathrm{L}^{-1}\right)$, Bivolje Polje (11.78 $\left.\mathrm{mg} \mathrm{L}^{-1}\right)$, Počitelj (11.69 $\left.\mathrm{mg} \mathrm{L}^{-1}\right)$, and Ševaš Polje (11.61 $\left.\mathrm{mg} \mathrm{L}^{-1}\right)$. The lowest average representations were located at Karaotok (6.64 $\left.\mathrm{mg} \mathrm{L}^{-1}\right)$ and Śkrka II (8.63 $\left.\mathrm{mg} \mathrm{L}^{-1}\right)$. This confirmed that higher salinity reduces the solubility of oxygen in water [12].

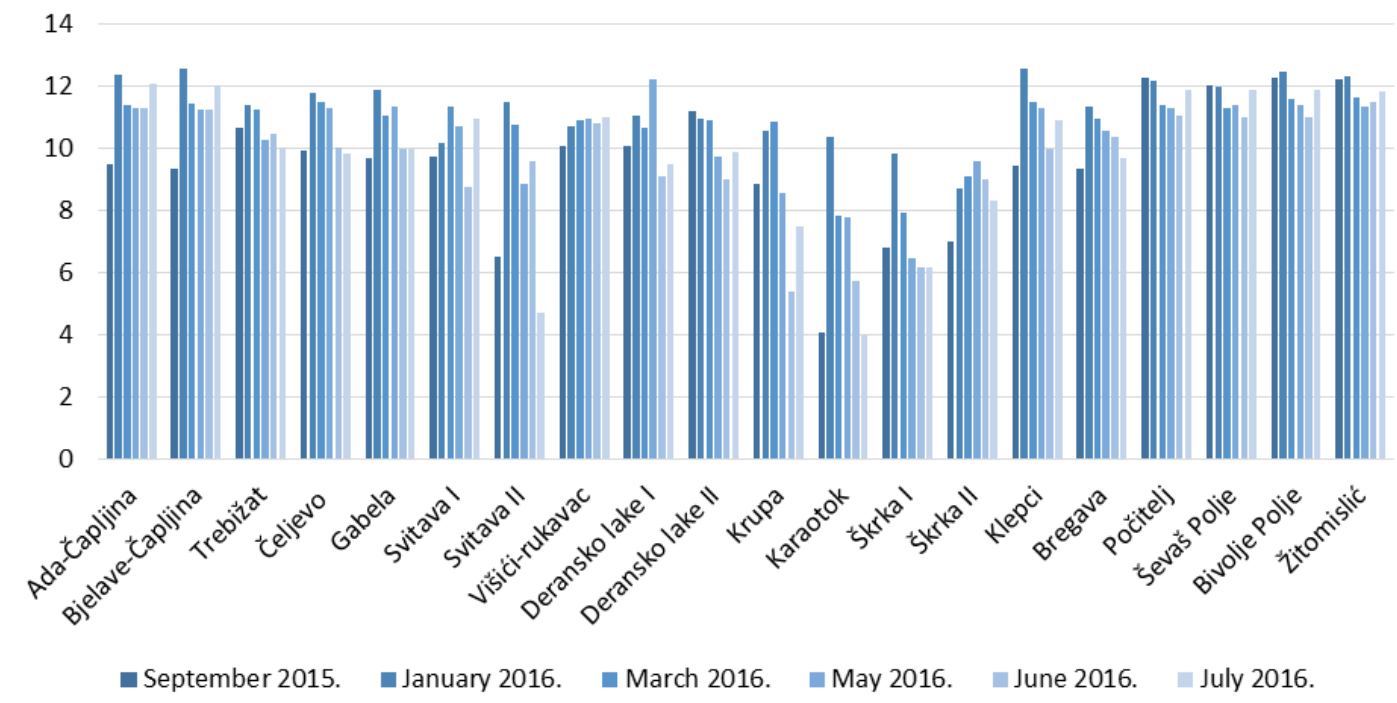

Figure 7 Dissolved oxygen (mg L-1) variations during research period

Saturation below $80 \%$ indicates increased oxygen consumption, which was found at Karaotok $\left(63.23 \% \mathrm{O}_{2}\right)$ and Škrka I $\left(72.7 \% \mathrm{O}_{2}\right)$ (Figures 8 and 9 ).

Ivanković, A, Ivanković, P, Petrović, D, Anđelić, T, Majstorović, J 
Oxygen saturation is a relative measure that indicates the percentage of oxygen dissolved in water at normal solubility at a given temperature. Critical conditions often occur in the summer in stagnant waters owing to the cumulative effect of high temperatures (less $\mathrm{O}_{2}$ ), enhanced degradation of organic matter (spent $\mathrm{O}_{2}$ ), and more rapid metabolism of the entire community [12].

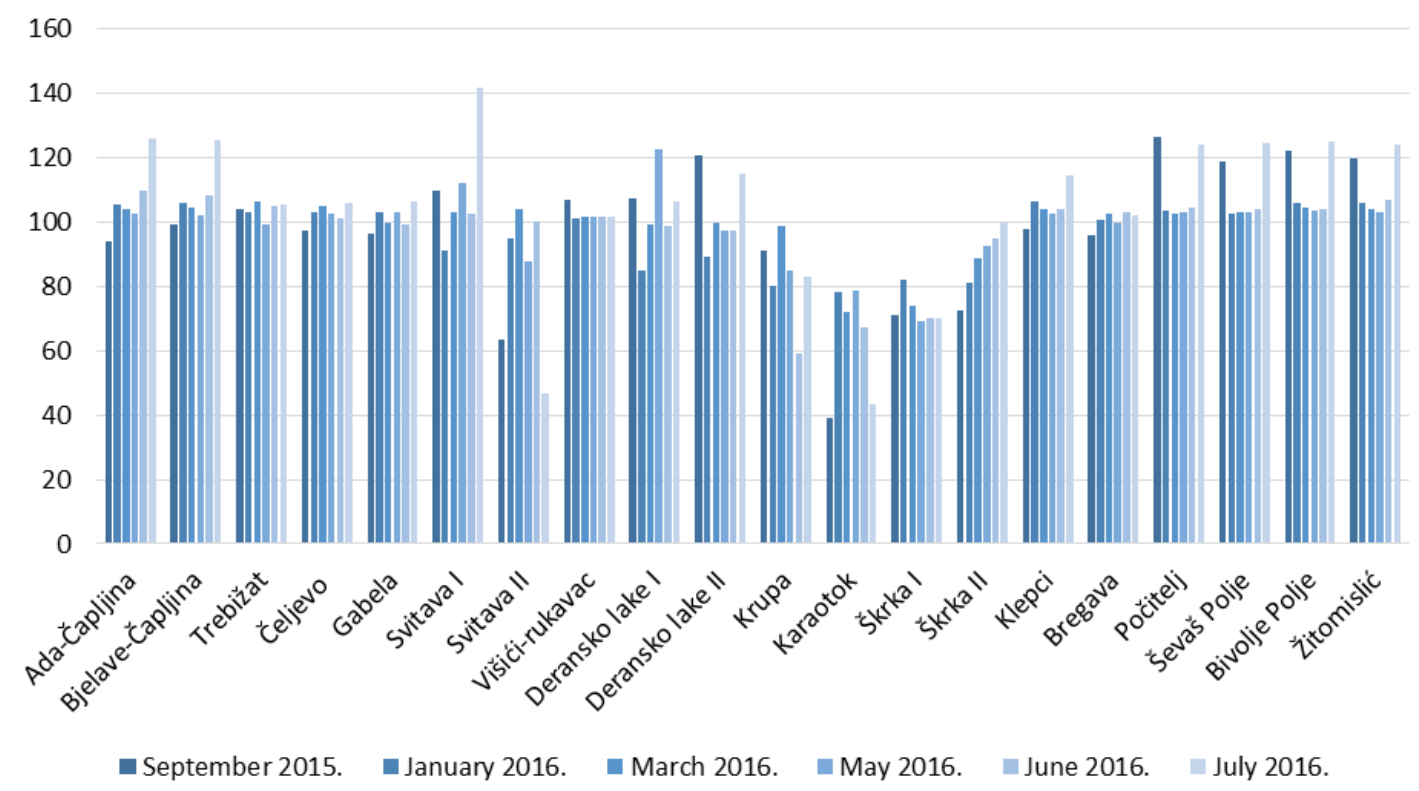

Figure 8 Oxygen saturation (\%) variations during research period

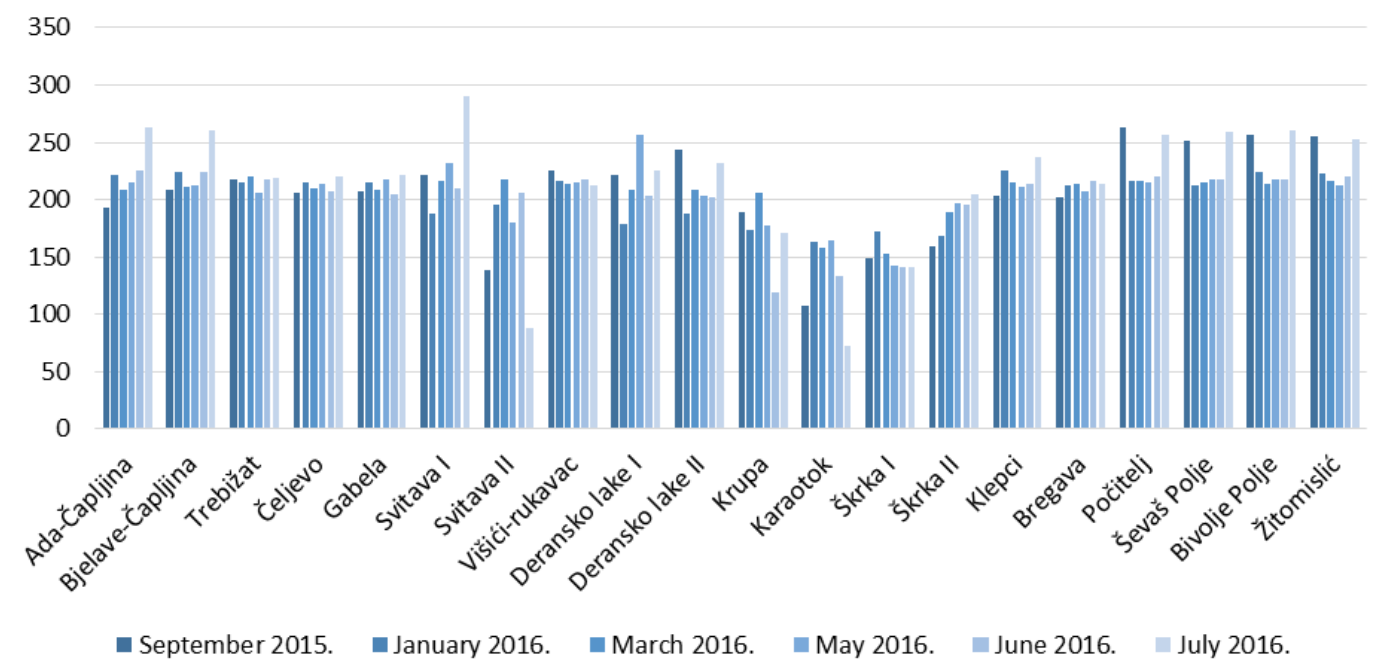

Figure 9 Oxygen pressure (mbar) variations during research period

The range of the measured pH of the studied area was from 7.2 at Škrka I in May 2016 to 8.5 at Počitelj in September 2015. ( \pm 1.3$)$. According to $\mathrm{pH}$, all ground water can be divided into two basic types: water with a neutral alkaline reaction ( $\mathrm{pH}$ rarely less than 6 , and in many cases increased to 10) and water that is acidic $(\mathrm{pH}<5)$. The measured $\mathrm{pH}$ values are fairly uniform, and their average value is $\mathrm{pH} 8$, as the lower water of the river contributes alkanes, suggesting an oligotrophic status of these waters [13].

The highest variations in the measured pH values were recorded during September 2016 and July 2016 $( \pm 1.1)$. The highest variation of $\mathrm{pH}$ was observed at Svitava II $( \pm 1.1)$, and the least oscillated $\mathrm{pH}$ value at Gabela $( \pm 0.1)$. pH is not a stable parameter and can significantly change during the year, particularly as a result of seasonal variations (Figure 10). 


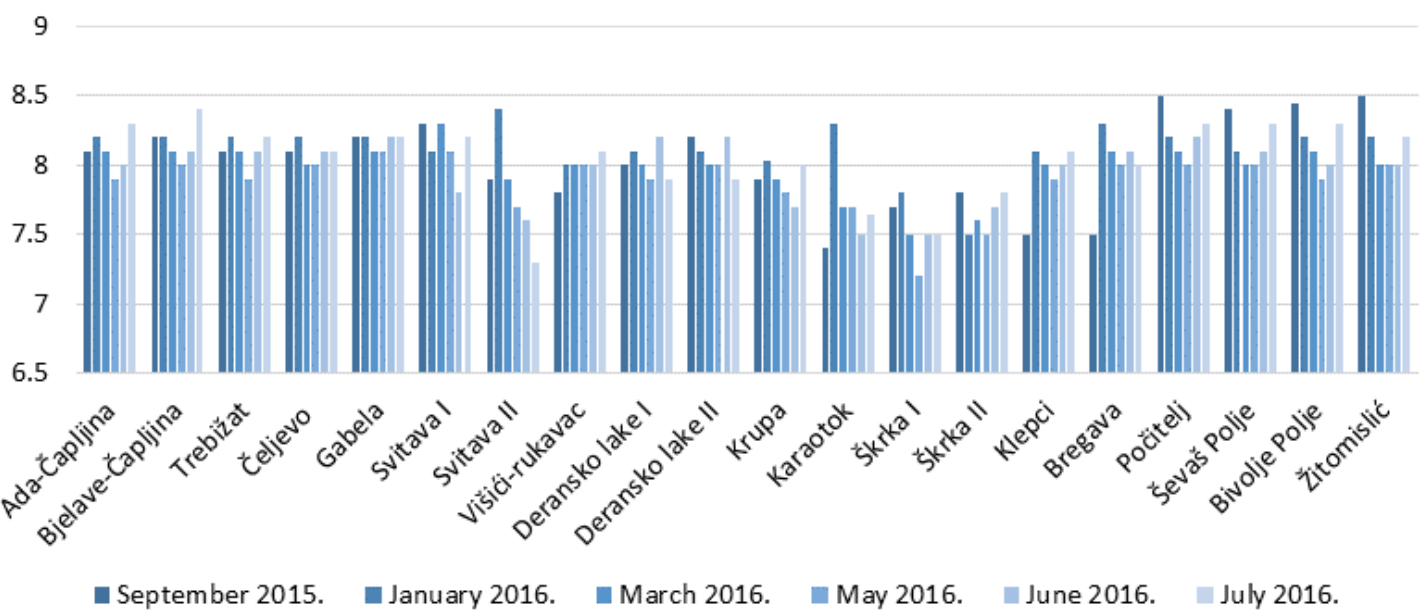

Figure $10 \mathrm{pH}$ variations during research period

\subsection{Statistical analysis}

According to all locations and all measurements, the variability of the temperature is moderate $(\mathrm{V}=30 \%)$. The average water temperature of the study area was $14.3^{\circ} \mathrm{C}$, and the standard deviation was $\sigma=4.5^{\circ} \mathrm{C}$.

The average electrical conductivity of the water study area was $560.8 \mu \mathrm{Scm}^{-1}\left(\sigma=458.52 \mu \mathrm{Scm}^{-1}\right)$. At an $82 \%$ variability, this is very strong ( $\mathrm{V} \geq 70 \%)$.

The average deviation from the average salinity ( $\sigma=0.26 \mathrm{PSU})$ and the variability of salinity ( $V=115 \%)$ were statistically established and very strong. The salinity of the study has a mean value of $0.23 \mathrm{PSU}$.

The average value of the total dissolved solids was $562.27 \mathrm{mg} \mathrm{L}^{-1}\left(\sigma=457.68 \mathrm{mg} \mathrm{L}^{-1}\right.$ with a very strong variability, $V=81 \%$ ).

In the investigated area, the average value of dissolved oxygen was $10.23 \mathrm{mg} \mathrm{L}^{-1}\left(\sigma=1.84 \mathrm{mg} \mathrm{L}^{-1}\right)$. The variability of dissolved oxygen was $18 \%$, which was relatively weak ( $V=10-30 \%)$.

The average percentage of dissolved oxygen in the investigated locations was $98.96 \%$ ( $\sigma=16.60 \%$ ). The variability of the percentage of dissolved oxygen was relatively low at $18 \%$.

The $\mathrm{pH}$ of the eighth among measured values was determined from the average deviation $(\sigma=0.25)$, and the $\mathrm{pH}$ variation was very weak at $\mathrm{V}=3 \%$.

There is a weak positive correlation $(r=0.17)$ between the temperature $(T)$ and electrical conductivity (CND), and the temperature climbed with the electrical conductivity of the water, which was in line with expectations [14].

There was a weak negative correlation $(r=-0.48)$ between the temperature $(T)$ and the total dissolved oxygen $\left(\mathrm{O}_{2}\right)$. Reducing the temperature of water increased the water saturation of dissolved oxygen in accordance with previous studies [14].

A moderate negative correlation $(r=-0.51)$ was found between the total dissolved oxygen $\left(\mathrm{O}_{2}\right)$ and salinity, which means that the total oxygen content decreased slightly with increasing salinity [15].

A functional positive relationship $(r=1)$ existed between the total dissolved solids (TDS) and electrical conductivity (CND). An increase in total dissolved solids also increased the electrical conductivity. This was expected since the electrical conductivity is an indirect measure of the total dissolved solids [16].

Table 1 lists the Pearson correlations of the phisicochemical parameters of four locations with increased salinity. There is a complete correlation $(r=0.92-0.97)$ between salinity and conductivity, and with the total dissolved solids at Trebižat, Karaotok, and Škrka I. Škrka II does not show a strong positive, rather a mediumstrong positive (Table 1). This is most likely because the salinity is highest and most variable at Škrka II. Based on the weak negative $(r=-0,33)$ and medium positive correlation $(r=0,51)$ between temperature and dissolved oxygen and oxygen saturation at the same location, investigating eventual eutrophication is recommended. 
Table 1 Pearson correlation: physical-chemical parameters of water at locations with higher salinity

\begin{tabular}{|c|c|c|c|c|c|c|c|c|}
\hline \multicolumn{9}{|c|}{ TREBIŽAT } \\
\hline & CND & TDS & SAL & $\rho$ & $\mathrm{pH}$ & $T$ & $\mathrm{DO}_{2}$ & $\% \mathrm{O}_{2}$ \\
\hline CND & 1 & & & & & & & \\
\hline TDS & 0.990856496 & 1 & & & & & & \\
\hline SAL & 0.936820966 & 0.925372598 & 1 & & & & & \\
\hline $\mathbf{P}$ & -0.98615553 & -0.97508028 & -0.8684885 & 1 & & & & \\
\hline $\mathrm{pH}$ & 0.062558149 & -0.00849331 & 0.21821789 & -0.02942 & 1 & & & \\
\hline$T$ & 0.59962587 & 0.661475925 & 0.454198984 & -0.6512 & 0.058425 & 1 & & \\
\hline $\mathrm{DO}_{2}$ & -0.56328021 & -0.61931704 & -0.31051872 & 0.657286 & 0.290608 & -0.88822 & 1 & \\
\hline$\% \mathrm{O}_{2}$ & -0.05473917 & -0.03295533 & 0.166697635 & 0.13413 & 0.721465 & 0.23886 & 0.226297 & 1 \\
\hline \multirow{2}{*}{\multicolumn{9}{|c|}{$\begin{array}{l}\text { KARAOTOK } \\
\text { KaTZSZ9900 }\end{array}$}} \\
\hline & & & & & & & & \\
\hline CND & 1 & & & & & & & \\
\hline TDS & 0.999787646 & 1 & & & & & & \\
\hline SAL & 0.968865821 & 0.970882388 & 1 & & & & & \\
\hline $\mathbf{P}$ & -0.98794707 & -0.98593421 & -0.93251698 & 1 & & & & \\
\hline $\mathrm{pH}$ & -0.56799806 & -0.56198904 & -0.38336650 & 0.678673 & 1 & & & \\
\hline $\mathrm{T}$ & 0.461870323 & 0.447473527 & 0.285655843 & -0.58483 & -0.88139 & 1 & & \\
\hline $\mathrm{DO}_{2}$ & -0.1666297 & -0.15566106 & 0.002562946 & 0.313743 & 0.850813 & -0.89679 & 1 & \\
\hline$\% \mathrm{O}_{2}$ & 0.217891137 & 0.224619134 & 0.338436254 & -0.07486 & 0.595271 & -0.60716 & 0.8929 & 1 \\
\hline \multirow{2}{*}{\multicolumn{9}{|c|}{$\begin{array}{c}\text { ŠKRKA I } \\
\text { S.2910004Z0 }\end{array}$}} \\
\hline & & & & & & & & \\
\hline CND & 1 & & & & & & & \\
\hline TDS & 0.99977505 & 1 & & & & & & \\
\hline SAL & 0.957172303 & 0.958181878 & 1 & & & & & \\
\hline $\mathbf{P}$ & -0.97198378 & -0.96927157 & -0.91397068 & 1 & & & & \\
\hline $\mathrm{pH}$ & -0.0419459 & -0.03572553 & 0.133250448 & 0.094179 & 1 & & & \\
\hline$T$ & 0.171118591 & 0.185184268 & 0.17474717 & -0.0037 & -0.31187 & 1 & & \\
\hline $\mathrm{DO}_{2}$ & -0.26446772 & -0.27281685 & -0.23677815 & 0.1683 & 0.623123 & -0.90329 & 1 & \\
\hline$\% \mathrm{O}_{2}$ & -0.33970441 & -0.34625283 & -0.26653114 & 0.275259 & 0.721997 & -0.8292 & 0.980227 & 1 \\
\hline $\mathrm{PO}_{2}$ & -0.19378582 & -0.20124892 & -0.13274275 & 0.118991 & 0.71628 & -0.8649 & 0.987863 & 0.987069 \\
\hline \multicolumn{9}{|c|}{ ŠKRKA II } \\
\hline CND & 1 & & & & & & & \\
\hline TDS & 0.999981316 & 1 & & & & & & \\
\hline SAL & 0.428159285 & 0.42452797 & 1 & & & & & \\
\hline$P$ & -0.41478009 & -0.41214274 & -0.95717231 & 1 & & & & \\
\hline $\mathrm{pH}$ & 0.209862861 & 0.21010458 & -0.58489765 & 0.638053 & 1 & & & \\
\hline$T$ & 0.161414904 & 0.160693618 & -0.39472995 & 0.578316 & 0.801134 & 1 & & \\
\hline $\mathrm{DO}_{2}$ & 0.270921848 & 0.268728332 & 0.818490243 & -0.70349 & -0.72793 & -0.3271 & 1 & \\
\hline$\% \mathrm{O}_{2}$ & 0.426141638 & 0.423264996 & 0.469345577 & -0.21989 & 0.010908 & 0.512961 & 0.63887 & 1 \\
\hline $\mathrm{PO}_{2}$ & 0.535921381 & 0.5335849 & 0.490943082 & -0.26363 & 0.004044 & 0.482506 & 0.651196 & 0.988884 \\
\hline
\end{tabular}

\section{CONCLUSIONS}

The maritime impact from the downstream side and the hydroelectric system at the upstream side, which affect the water regime in the lower course of the Neretva River, is very complex.

The water of the lower Neretva is within the limit values for water quality classes I and II according to the regulation on classification of waters $\mathrm{B} \& \mathrm{H}$.

The proposal is to continue research in order to obtain an overall picture of the state of the water quality of the lower course of the Neretva River. Everything that occurs in the lower course of the river is the result of what occurs upstream, and the impact of salt water from the Metković downstream.

During the summer period, flows into the Neretva River are very small, and the impact of tides is greatest.

Ivanković, A, Ivanković, P, Petrović, D, Anđelić, T, Majstorović, J 
The average deviation from the average salinity is $\sigma=0.26 \mathrm{PSU}$. The total oxygen content decreases slightly with increasing salinity. Salinity is highest and most variable at Škrka II.

The sea penetration through the river flow should be investigated. It is known that the Neretva River was under the influence of the tides in direct contact with the sea until Dračevo.

It is recommended to continue research at four locations with increased salinity: Trebižat, Karaotok, Škrka I, and Škrka II, with regard to hydrological and biological aspects, especially eutrophication.

\section{References}

[1] Juračić, M. 1998: On the origin and changes of the Neretva River delta. Dubrovnik, Časopis za književnost i znanost, Nova serija, 9, pp. 228-232 (in Croatia)

[2] Margeta, J.; Fistanić, I. 2000: System management and monitoring of the Neretva river basin. Građevinar, 52, 6, pp. 331-338. http://hrcak.srce.hr/13088, Accessed 15 January 2017) (in Croatian)

[3] Jurina, I.; Ivanić, M.; Vdović, N.; Troskot-Čorbić, T.; Lojen, S.; Mikac, N.; Sondi, I. 2015: Deposition of trace metals in sediments of the deltaic plain and adjacent coastal area (the Neretva River, Adriatic Sea). Journal of Geochemical Exploration, 157, pp. 120-131. https://doi.org/10.1016/i.gexplo.2015.06.005

[4] Vranješ, M., Prskalo, M.; Džeba, T. 2013: Hydrology and Hydrogeology basin Neretva and Trebišnjica, review of the construction of part of the HPP system - Upper horizons, Elektronic Collection of Papers of the Faculty of Civil Engineering, 5, pp. 1-23, http://gf.sve-mo.ba/e-zbornik/e_zbornik_05_01.pdf, Accessed 24 January 2017) (in Croatian)

[5] Management Strategy of the Federation of Bosnia and Herzegovina 2010-2022, Government of Federation B\&H, Sarajevo, 2010. (in Croatian)

[6] Jelavić, E.; Jaćimovska, M.; Matoničkin Kepčija, R. 2014: Influence of increased salinity on protozoa in activated sludge. Proceedings of the 4th Congress of Ecologists of Macedonia with International Participation, Macedonian Ecological Society, pp. 179-184.

[7] Edmunds, W.M.; Shand, P.; P. Hart, P.; Ward, R.S. 2003: The natural (baseline) quality of groundwater: a UK pilot study, Science of The Total Environment, 310 (1-3), pp. 25-35. https://doi.org/10.1016/S0048-9697(02)00620-4

[8] APHA (American Public Health Association) 1998; Standard Methods for the Examination of Water and Wastewater, 20th Edition. Washington, DC 20005-2605.

[9] Pavletić, Z.; Matoničkin, I. 1965: Biological classification of the upper river flows karst, Acta Botanica Croatica X X IV, Zagreb. (in Croatian)

[10] Todorović, B. 2005: Neretva River Delta-from wetlands to intensive agriculture, http://www.geografija.hrl, Accessed 31 March 2017 (in Croatian)

[11] Regulation on classification of waters and coastal waters of Yugoslavia within the borders of the Socialist Republic of Bosnia and Herzegovina 1980: Official Journal SRBiH, I.V. 221, http://fmpvs.gov.ba/upload_files/1440587792191310 b.pdf, Accessed 29 March 2017 (in Croatian)

[12] Matoničkin Kepčija, R. 1996: The study of water - Manual measurements globe. http://public.carnet.hr/globe/prirucnik/voda.PDF, Accessed 31 March 2017 (in Croatian)

[13] Brancelj, A.J. et.al. 2002: High-mountain Lakes in the Eastern Part of the Julian Alps, National Institute of Biology, Založba ZRC, Ljubljana 2002. (in Slovenian)

[14] Moore, W.J. 1990: Phisical chemistry, Longman Scientific \& Technical, Essex

[15] Zaccone, R.; Caruso, G.; Calı, C. 2002: Heterotrophic bacteria in the northern Adriatic Sea: Seasonal changes and ectoenzyme profile, Marine Environmental Research, 54, 1, pp. 1-19. https://doi.org/10.1016/S0141-1136(02)00089-2

[16] Walton, N.R.G. 1989: Electrical Conductivity and Total Dissolved Solids-What is Their Precise Relationship?, Desalination, 72, 3, pp. 275-292, https://doi.org/10.1016/0011-9164(89)80012-8

Please cite this article as:

Ivanković, A., Ivanković, P., Petrović, D., Anđelić, T., Majstorović, J.: Salinity and physicochemical water parameters of lower flow of river Neretva, Electronic Journal of the Faculty of Civil Engineering Osijek-eGFOS, 15, pp. 75-84, https://doi.org/10.13167/2017.15.7 